Bull. Chem. Soc. Ethiop. 2018, 32(3), 513-522.

ISSN 1011-3924

(c) 2018 Chemical Society of Ethiopia and The Authors

Printed in Ethiopia

DOI: https://dx.doi.org/10.4314/bcse.v32i3.10

\title{
NOVEL SYNTHESIS, RING TRANSFORMATION AND ANTICANCER ACTIVITY OF 1,3-THIAZINE, PYRIMIDINE AND TRIAZOLO[1,5- $a$ ]PYRIMIDINE DERIVATIVES
}

\author{
Hassan A. El-Sayed ${ }^{*}$, Maher M. El-Hashash ${ }^{2}$ and Aiada E. Ahmed ${ }^{3}$ \\ ${ }^{1}$ Department of Chemistry, Faculty of Science, Zagazig University, Zagazig, Egypt \\ ${ }^{2}$ Department of Chemistry, Faculty of Science, Ain-Shams University, Cairo, Egypt \\ ${ }^{3}$ Department of Chemistry, Faculty of Education, Al-Gabel Al-Gharbi University, Kikla, Libya
}

(Received March 20, 2017; Revised July 9, 2018; Accepted July 12, 2018)

\begin{abstract}
Synthesis, heterocyclization and anticancer activity of a new series of heterocyclic compounds are described. Aminothiazine 1 was obtained from the base induced condensation of thiourea, benzaldehyde and ethyl cyanoacetate. The synthesis of $\mathrm{N}$-phenyl amino pyrimidine derivative $\mathbf{2}$ was obtained as a result of reaction of aniline with compound $\mathbf{1}$. Compound $\mathbf{2}$ underwent ring opening and recyclization upon reaction with $\mathrm{HCl}$ or $\mathrm{H}_{2} \mathrm{O}_{2} /$ $\mathrm{NaOH}$ to afford the acid derivative 3 or oxazine 4, respectively. Thiazine 1 undergoes ring transformation upon the effect of $\mathrm{NH}_{2} \mathrm{OH} . \mathrm{HCl}$ to produce pyrimidine derivative $\mathbf{5}$. Heterocyclization of compound $\mathbf{1}$ with thiosemicarbazide followed by oxidation with $\mathrm{I}_{2} / \mathrm{AcOH}$ afforded triazolopyrimidine 6 and 7 , respectively. Alkylation of compound $\mathbf{1}$ was promoted by reaction of $\mathbf{1}$ with ethyl iodide to give alkylated thiazine $\mathbf{8}$ which in turn undergo ring transformation when subjected to reaction with hydrazine hydrate to give pyrazole derivative $\mathbf{9}$. Refluxing of amino-1,3-thiazine derivative 1 with ethyl bromoacetate in the presence of $\mathrm{Et}_{3} \mathrm{~N}$ produce the alkylated pyrimidine product 10. Hydrazonolysis of 1,3-thiazine $\mathbf{1}$ with hydrazine or phenyhydrazine gave pyrimidine derivatives 11a,b, respectively. Compound 11b was cyclized with carbon disulfide or formaldehyde to produce triazolopyrimidines $\mathbf{1 2}$ and 13, respectively. Some of the new compounds were screened for anticancer activity and significant results were found for some compounds.
\end{abstract}

KEY WORDS: 1,3-Thiazine, Pyrimidine, Triazole, Pyrazole, Anticancer activity

\section{INTRODUCTION}

1,3-Thiazine derivatives are class of compounds with potential biological activity, such as growth promoting activities [1], anti-fungal activity [2], antiproliferative [3], anti-tumor activity [4], anticancer [5], analgesic activity [6,7], calming activity [8], anticonvulsant activity [9], antibiotic alctivity [10,11], anti-inflammatory [11, 12], antimicrobial [13], antimycobacterial [14], antibacterial [15] and antihypertesive [7, 16]. On the other hand, pyrimidine derivatives are known to be biologically active compounds and have shown wide range of biological activities like antitubercular [17], antimicrobial, antioxidant and anti-inflammatory [18-20], anticancer [21], analgesic, anti-fungal activity, anti-leishmanial, antiviral activity [22, 23]. Recently, our research field focused to design and synthesis of biologically active heterocyclic compounds from readily available reagents [24-26]. Herein, we hope to use a simple and facile approach to synthesize a novel series of heterocyclic systems utilizing 2-amino-4-oxo-4-phenyl-4H-1,3thiazine-5-carbonitrile as a synthetic precursor.

\section{EXPERIMENTAL}

All melting points are uncorrected and were measured using an Electro thermal Al 9100 apparatus. TLC was performed on Merck silica gel $60 \mathrm{~F}_{245}$ with detection by UV light. The IR spectra (KBr disc) were recorded on a Pye Unicam Sp-3-300 or a Shimadzu FTIR 8101 PC

*Corresponding author. E-mail: hasanneg@gmail.com

This work is licensed under the Creative Commons Attribution 4.0 International License 
infrared spectrophotometer. The ${ }^{1} \mathrm{H}$ and ${ }^{13} \mathrm{C}$ NMR spectra were determined with JEOL-JNMLA $300 \mathrm{MH}_{\mathrm{Z}}$ spectrometer. The chemical shifts are expressed on the (ppm) scale using TMS as the standard reference. Elemental analysis determined on a Perkin Elmer 240 (microanalysis). The antitumor activity was performed at micro analytical center, Cairo Univeristy, Cairo, Egypt.

2-Amino-4-oxo-4-phenyl-4H-1,3-thiazine-5-carbonitrile (1)

A mixture of thiourea $(0.01 \mathrm{~mol})$, ethyl cyanoacetate $(0.01 \mathrm{~mol})$, benzaldehyde $(0.01 \mathrm{~mol})$, and anhydrous potassium carbonate $(0.01 \mathrm{~mol})$ in absolute ethanol $(25 \mathrm{~mL})$ was heated under reflux for 6 hours. The reaction mixture was cooled and triturated with water and neutralized with glacial acetic acid, the formed precipitate was filtered, washed with water, dried and crystallized from acetic acid to give white crystals from 1, yield 65\%, m.p. 296-300 ${ }^{\circ} \mathrm{C}$. IR $\left(\mathrm{KBr} \mathrm{cm}^{-1}\right)$ : 3196, $3153\left(\mathrm{NH}_{2}\right), 2232(\mathrm{C} \equiv \mathrm{N}), 1688(\mathrm{C}=\mathrm{O}) .{ }^{1} \mathrm{H}$ NMR (DMSO-d 6 , $\left.\delta \mathrm{ppm}\right): 7.32-7.68(\mathrm{~m}, 5 \mathrm{H}$, Ar-H), $13.07\left(\mathrm{NH}_{2}\right) .{ }^{13} \mathrm{C}$ NMR (DMSO-d 6 , $\left.\delta \mathrm{ppm}\right): 90.5,114.8(\mathrm{C} \equiv \mathrm{N}), 128.4,128.7,129.6$, 132.0, 158.6, 161.1, 176.4 (Ar-C and $\mathrm{C}=\mathrm{O}$ ). Anal. calcd for $\mathrm{C}_{11} \mathrm{H}_{7} \mathrm{~N}_{3} \mathrm{OS}$ (229.26): $\mathrm{C}, 57.63$; $\mathrm{H}$, 3.08; N, 18.33. Found: 57.58; H, 3.14; N, 18.26.

\section{2-Amino-6-oxo-1,4-diphenyl-1,6-dihydropyrimidine-5-carbonitrile (2)}

To a solution of 1,3-thiazine $1(0.01 \mathrm{~mol})$ in n-butanol $(30 \mathrm{~mL})$, aniline $(0.01 \mathrm{~mol})$ was added, the reaction mixture was refluxed for 8 hours, the reaction mixture left to cool and kept at room temperature overnight, the formed precipitate was filtered off, dried and crystallized from ethanol to give yellow crystals from 2, yield 90\%, m.p. $260-265^{\circ} \mathrm{C}$. IR $\left(\mathrm{KBr} \mathrm{cm}{ }^{-1}\right): 3427\left(\mathrm{NH}_{2}\right)$, $2206(\mathrm{C} \equiv \mathrm{N}), 1675(\mathrm{C}=\mathrm{O}) .{ }^{1} \mathrm{H}$ NMR $\left(\mathrm{DMSO}_{6}, \delta \mathrm{ppm}\right): 7.49-7.69(\mathrm{~m}, 10 \mathrm{H}, \mathrm{Ar}-\mathrm{H}), 12.56(\mathrm{~s}$, $\left.2 \mathrm{H}, \mathrm{NH}_{2}\right) .{ }^{13} \mathrm{C}$ NMR (DMSO-d 6 , $\left.\delta \mathrm{ppm}\right): 89.1,92.3,116.10(\mathrm{C} \equiv \mathrm{N}), 126.3,128.2,128.5,131.4$, 132.0, 133.1, 141.8, 159.8, 163.0 and $178.4($ Ar- $\mathrm{H}$ and $\mathrm{C}=\mathrm{O})$. Anal. calcd for $\mathrm{C}_{17} \mathrm{H}_{12} \mathrm{~N}_{4} \mathrm{O}$ (288.30): C, 70.82; H, 4.20; N, 19.43. Found: C, 70.87; H, 4.26; N, 19.39.

(Amino (phenylamino) methylene) amino)-2-cyano-3-phenylacrylic acid (3)

2-Amino pyrimidine $2(0.01 \mathrm{~mol})$ in ethanol $(20 \mathrm{~mL})$ and concentrated hydrochloric acid $(1 \mathrm{~mL})$ was added, then refluxed for 3 hours, the resulting mixture was neutralized with sodium hydroxide solution, then concentrated and left to cool, the solid obtained was dried and washed by petroleum ether $60-80{ }^{\circ} \mathrm{C}$ to give yellow crystals from 3 , yield $52 \%$, m.p. $>300{ }^{\circ} \mathrm{C}$. IR $(\mathrm{KBr}$ $\left.\mathrm{cm}^{-1}\right): 3410,3172(\mathrm{OH}, \mathrm{NH}), 2208(\mathrm{C} \equiv \mathrm{N}), 1651(\mathrm{C}=\mathrm{O}) .{ }^{1} \mathrm{H}$ NMR $\left(\mathrm{DMSO}-\mathrm{d}_{6}, \delta \mathrm{ppm}\right): 5.60(\mathrm{~s}$, $\left.2 \mathrm{H}, \mathrm{NH}_{2}\right), 7.41-7.73(\mathrm{~m}, 10 \mathrm{H}, \mathrm{Ar}-\mathrm{H}), 10.0(\mathrm{~s}, 1 \mathrm{H}, \mathrm{NH}), 11.5(\mathrm{~s}, 1 \mathrm{H}, \mathrm{OH})$. Anal. calcd for $\mathrm{C}_{17} \mathrm{H}_{14} \mathrm{~N}_{4} \mathrm{O}_{2}$ (306.32): C, 66.66; H, 4.61; N, 18.29. Found: C, 66.61; H, 4.68; N, 18.35.

2-Imino-4-oxo-3,6-diphenyl-3,4-dihydro-2H-1,3-oxazine-5-carbontrile (4)

A mixture of 2-amino pyrimidine $2(0.01 \mathrm{~mol})$ and sodium hydroxide solution $(20 \mathrm{~mL})$ [prepared from $\mathrm{NaOH}(0.02 \mathrm{~mol})$ in ethanol $(20 \mathrm{~mL})]$, hydrogen peroxide $(1 \mathrm{~mL})$ was added drop wise with stirring at room temperature for 2 hours, the reaction mixture was triturated with water and neutralized with concentrated hydrochloric acid and stirred, the resulting solid was dried and crystallized from methanol to give white crystals from 4 , yield $40 \%$, m.p. $>300{ }^{\circ} \mathrm{C}$. IR $\left(\mathrm{KBr} \mathrm{cm}^{-1}\right): 3149(\mathrm{NH}), 2206(\mathrm{C} \equiv \mathrm{N}), 1649(\mathrm{C}=\mathrm{O}) .{ }^{1} \mathrm{H}$ NMR (DMSO-d $\left.{ }_{6}, \delta \mathrm{ppm}\right): 7.41-7.68(\mathrm{~m}$, $10 \mathrm{H}, \mathrm{Ar}-\mathrm{H}), 10.10(\mathrm{NH})$. Anal. calcd for $\mathrm{C}_{17} \mathrm{H}_{11} \mathrm{~N}_{3} \mathrm{O}_{2}$ (282.29): C, 70.58; H, 3.83; N, 14.33 . Found: C, 70.56; H, 3.77; N, 14.29.

\section{2-Amino-1-hydroxy-4-oxo-6-phenyl-1,4-dihydropyrimidine-5-carbonitrile (5)}

A mixture of 2-aminothiazine $1(0.01 \mathrm{~mol})$, hydroxylamine hydrochloride $(0.02 \mathrm{~mol})$, and (3 drops) of triethyl amine. in n-butanol $(20 \mathrm{~mL})$ was refluxed for 8 hours, after cooling, the 
formed precipitate was filtered off, dried and crystallized by acetic acid to give brown crystals from 5, yield 77\%, m.p. $>310{ }^{\circ} \mathrm{C}$. IR $\left(\mathrm{KBr} \mathrm{cm}^{-1}\right)$ : $3427\left(\mathrm{OH}, \mathrm{NH}_{2}\right), 2210(\mathrm{C} \equiv \mathrm{N}), 1635(\mathrm{C}=\mathrm{O})$. ${ }^{1} \mathrm{H}$ NMR (DMSO-d 6 , $\delta$ ppm): $6.95\left(\mathrm{~s}, 2 \mathrm{H}, \mathrm{NH}_{2}\right), 7.50-7.79(\mathrm{~m}, 5 \mathrm{H}, \mathrm{Ar}-\mathrm{H}), 11.69(\mathrm{~s}, 1 \mathrm{H}, \mathrm{OH})$. ${ }^{13} \mathrm{C}$ NMR (DMSO-d $\left.{ }_{6}, \delta \mathrm{ppm}\right): 84.7,117.1(\mathrm{C} \equiv \mathrm{N}), 128.1,128.2,130.8,136.5,156.3,161.5$ and 171.5 (Ar-C and $\mathrm{C}=\mathrm{O})$. Anal. calcd for $\mathrm{C}_{11} \mathrm{H}_{8} \mathrm{~N}_{4} \mathrm{O}_{2}$ (228.21): C, 57.89; H, 3.53; N, 24.55. Found: C, 57.81; H, 3.58; N, 24.49.

\section{2-Mercapto-5-oxo-7-phenyl-1,5-dihydro[1,2,4] triazolo[1,5-a]pyrimidine-6-carbonitrile (6)}

A mixture of 2-aminothiazine $2(0.01 \mathrm{~mol})$, thiosemicarbazide $(0.01 \mathrm{~mol})$, and (3 drops ) of triethylamine in n-butanol $(20 \mathrm{~mL})$ was refluxed for 6 hours, the reaction mixture was kept at room temperature overnight, the precipitate obtained was filtered off, dried and crystallized from ethanol to yield yellow crystals from 6, yield $68 \%$, m.p. $220-226^{\circ} \mathrm{C}$. IR $\left(\mathrm{KBr} \mathrm{cm}^{-1}\right): 3376$ $(\mathrm{NH}), 2213(\mathrm{C} \equiv \mathrm{N}), 1622(\mathrm{C}=\mathrm{O}), 1233(\mathrm{SH}) .{ }^{1} \mathrm{H}$ NMR (DMSO-d $\left.\mathrm{d}_{6}, \delta \mathrm{ppm}\right): 7.51-7.71(\mathrm{~m}, 5 \mathrm{H}$, Ar-H), 8.61 (s, 1H, NH), 12.25 (s, 1H, SH). Anal. calcd for $\mathrm{C}_{12} \mathrm{H}_{7} \mathrm{~N}_{5} \mathrm{OS}$ (269.28): C, 53.52; H, $2.62 ; \mathrm{N}, 26.01$. Found: C, 53.56; H, 2.59; N, 25.95.

6-Cyano-5-oxo-7-phenyl-1,5-dihydro[1,2,4]triazolo[1,5-a]pyrimidine-2-sulfonic acid (7)

A mixture of pyrimidine derivative $6(0.01 \mathrm{~mol})$ and iodine $(0.01 \mathrm{~mol})$ in glacial acetic acid $(20$ $\mathrm{mL}$ ) was sterrid for 2 hours, the formed precipitate was filtered off, washed with water, dried and crystallized by ethanol to yield white crystals from 7, yield $78 \%$, m.p. $310-312^{\circ} \mathrm{C}$. IR ( $\mathrm{KBr}$ $\left.\mathrm{cm}^{-1}\right): 3448(\mathrm{OH}, \mathrm{NH}), 2230(\mathrm{C} \equiv \mathrm{N}), 1679(\mathrm{C}=\mathrm{O}) .{ }^{1} \mathrm{H}$ NMR (DMSO-d $\left.\mathrm{d}_{6}, \delta \mathrm{ppm}\right): 7.54-7.68(\mathrm{~m}$, $5 \mathrm{H}, \mathrm{Ar}-\mathrm{H}), 13.17(\mathrm{~s}, 1 \mathrm{H}, \mathrm{NH}), 13.31(\mathrm{~s}, 1 \mathrm{H}, \mathrm{OH})$. Anal. calcd for $\mathrm{C}_{12} \mathrm{H}_{7} \mathrm{~N}_{5} \mathrm{O}_{4} \mathrm{~S}$ (317.28): $\mathrm{C}$, 45.43; H, 2.22; N, 22.07. Found: C, 45.38; H, 2.27; N, 22.13.

\section{2-(Diethylamino)-4-oxo-6-phenyl-4H-1,3-thiazine-5-carbonitrile (8)}

A mixture of 2-aminothiazine $1(0.01 \mathrm{~mol})$, ethyl iodide $(0.01 \mathrm{~mol})$, and sodium hydroxide solution [prepared from sodium hydroxide $(0.01 \mathrm{~mol})$ in ethanol $(30 \mathrm{~mL})$ was refluxed for 3 hours, after cooling, the reaction mixture was triturated with water and neutralized with concentrated hydrochloric acid, the resulting precipitate was filtered off, dried and crystallized from ethanol to give white crystals from 8, yield $69 \%$, m.p. $230-235{ }^{\circ} \mathrm{C}$.IR $\left(\mathrm{KBr} \mathrm{cm}^{-1}\right): 2218$ $(\mathrm{C} \equiv \mathrm{N}), 1657(\mathrm{C}=\mathrm{O}) .{ }^{1} \mathrm{H}$ NMR (DMSO-d 6 , $\left.\delta \mathrm{ppm}\right): 1.32\left(\mathrm{t}, 3 \mathrm{H}, \mathrm{CH}_{2} \mathrm{C}_{3}\right), 3.25\left(\mathrm{q}, 2 \mathrm{H}, \mathrm{C}_{2} \mathrm{CH}_{3}\right)$, 7.29-7.95 (m, 5H, Ar-H). Anal. calcd for $\mathrm{C}_{15} \mathrm{H}_{15} \mathrm{~N}_{3} \mathrm{OS}$ (285.36): C, 63.13; H, 5.30; N, 14.73. Found: C, 63.08; H, 5.36; N, 17.69.

\section{5-Oxo-3-phenyl-4,5-dihydro-1H-pyrazole-4-carbonitrile (9)}

A mixture of 2-amino thiazine $8(0.01 \mathrm{~mol})$, hydrazine hydrate $(0.01 \mathrm{~mol})$ in $\mathrm{n}$-butanol $(20 \mathrm{~mL})$ was refluxed for 10 hours, after cooling, the formed precipitate was filtered off, dried and crystallized from ethanol/acetic acid to give yellow crystals from 9 yield $77 \%$, m.p. $267-270{ }^{\circ} \mathrm{C}$. IR $\left(\mathrm{KBr} \mathrm{cm}^{-1}\right): 3436(\mathrm{NH}), 2221(\mathrm{C} \equiv \mathrm{N}), 1646(\mathrm{C}=\mathrm{O}) .{ }^{1} \mathrm{H}$ NMR (DMSO-d $\left.{ }_{6}, \delta \mathrm{ppm}\right): 7.47-7.78$ (m, $5 \mathrm{H}, \mathrm{Ar}-\mathrm{H}), 9.84\left(\mathrm{~m}, 2 \mathrm{H}, 2 \mathrm{NH}, \mathrm{D}_{2} \mathrm{O}\right.$ exchangeable). Anal. calcd for $\mathrm{C}_{10} \mathrm{H}_{7} \mathrm{~N}_{3} \mathrm{O}$ (185.06): $\mathrm{C}$, 64.86; H, 3.81; N, 22.69. Found: C, 64.91; H, 3.75; N, 22.75.

\section{Diethyl-2,2'-((5-cyano-4-oxo-6-phenyl-4H-1,3-thiazin-2-yl)azanediyl) diacetate (10)}

A mixture of 2-aminothiazine $1(0.01 \mathrm{~mol})$, ethyl bromoacetate $(0.01 \mathrm{~mol})$, and (3 drops) of triethylamine in ethanol $(25 \mathrm{~mL})$ was refluxed for 6 hours, the resulting precipitate was filtered off, washed with water, dried and crystallized from ethanol to give yellow crystals of 10, yield $80 \%$, m.p. $224-230^{\circ} \mathrm{C}$. IR $\left(\mathrm{KBr} \mathrm{cm}^{-1}\right): 2223(\mathrm{C} \equiv \mathrm{N}), 1735(\mathrm{C}=\mathrm{O}$, ester $), 1661(\mathrm{C}=\mathrm{O}$, amide $) .{ }^{1} \mathrm{H}$ NMR (DMSO-d $\left.\mathrm{d}_{6}, \delta \mathrm{ppm}\right): 1.11\left(\mathrm{t}, 3 \mathrm{H}, \mathrm{J}=5.7 \mathrm{~Hz}, \mathrm{CH}_{2} \mathrm{C}_{3}\right), 2.50\left(\mathrm{~s}, 2 \mathrm{H}, \mathrm{CH}_{2}\right), 4.08(\mathrm{q}, 2 \mathrm{H}, \mathrm{J}=$ 
$\left.5.7 \mathrm{~Hz}, \mathrm{CH}_{2} \mathrm{CH}_{3}\right), 7.54-7.92(\mathrm{~m}, 5 \mathrm{H}, \mathrm{Ar}-\mathrm{H}) .{ }^{13} \mathrm{C}$ NMR (DMSO-d 6 , $\left.\delta \mathrm{ppm}\right): 13.8\left(\mathrm{CH}_{3} \mathrm{CH}_{2}\right), 32.9$ $\left(\mathrm{NCH}_{2} \mathrm{CO}\right), 61.3\left(\mathrm{O}_{-} \mathrm{CH}_{2} \mathrm{CH}_{3}\right), 94.3,115.6(\mathrm{C} \equiv \mathrm{N}), 127.1,128.5,128.6,129.8,131.8,138.0$, 165.7 and $167.9\left(\mathrm{Ar}-\mathrm{C}\right.$ and $2 \mathrm{C}=\mathrm{O}$ ). Anal. calcd for $\mathrm{C}_{19} \mathrm{H}_{19} \mathrm{~N}_{3} \mathrm{O}_{5} \mathrm{~S}$ (401.44): C, 56.85; H, 4.77; $\mathrm{N}, 10.47$. Found: C, 56.92; H, 4.81; N, 10.40.

\section{1,2-Diamino-4-oxo-6-phenyl-1,4-dihydropyrimidine-5-carbonitrile (11a)}

To a solution of 1,3-thiazine $1(0.0 .1 \mathrm{~mol})$ in n-butanol $(30 \mathrm{~mL})$, hydrazine hydrate $(0.02 \mathrm{~mol})$ was added, the reaction mixture was refluxed for 8 hours, the reaction mixture left to cool and kept at room temperature overnight, the formed precipitate was filtered off, dried and crystallized from ethanol to give orange crystals from 11a, yield $87 \%$, m.p. $236-243{ }^{\circ} \mathrm{C}$. IR ( $\mathrm{KBr}$ $\left.\mathrm{cm}^{-1}\right): 3456,3221\left(2 \mathrm{NH}_{2}\right), 2218(\mathrm{C} \equiv \mathrm{N}), 1652(\mathrm{C}=\mathrm{O}) .{ }^{1} \mathrm{H}$ NMR (DMSO-d $\left.{ }_{6}, \delta \mathrm{ppm}\right): 7.15(\mathrm{~s}, 2 \mathrm{H}$, $\left.\mathrm{NH}_{2}\right), 7.45-7.78(\mathrm{~m}, 5 \mathrm{H}, \mathrm{Ar}-\mathrm{H}), 9.85\left(\mathrm{~s}, 2 \mathrm{H}, \mathrm{NH}_{2}\right)$. Anal. calcd for $\mathrm{C}_{11} \mathrm{H}_{9} \mathrm{~N}_{5} \mathrm{O}(227.22)$ : C, 58.14; H, 3.99; N, 30.82. Found: C, 58.07; H, 3.91; N, 30.87 .

2-Amino-4-oxo-6-phenyl-1-(phenylamino)-1,4-dihydropyrimidine-5-carbonitrile (11b)

To a solution of 1,3-thiazine $1(0.01 \mathrm{~mol})$ in n-butanol $(30 \mathrm{~mL})$, phenyl hydrazine $(0.01 \mathrm{~mol})$ was added, the reaction mixture was refluxed for 12 hours, the reaction mixture left to cool and kept at room temperature overnight, the formed precipitate was filtered off, dried and crystallized from ethanol to give brown crystals from 11b, yield $80 \%$, m.p. $246-252{ }^{\circ} \mathrm{C}$. IR ( $\mathrm{KBr}$ $\left.\mathrm{cm}^{-1}\right)$ : 3427, 3293, $3139\left(\mathrm{NH}, \mathrm{NH}_{2}\right), 2206(\mathrm{C} \equiv \mathrm{N}), 1634(\mathrm{C}=\mathrm{O}) .{ }^{1} \mathrm{H}$ NMR (DMSO-d $\left.{ }_{6}, \delta \mathrm{ppm}\right)$ : 7.74-8.08 (m, 10H, Ar-H), $10.38\left(\mathrm{~s}, 2 \mathrm{H}, \mathrm{NH}_{2}\right), 11.76(\mathrm{~S}, 1 \mathrm{H}, \mathrm{NH}) .{ }^{13} \mathrm{C}$ NMR $\left(\mathrm{DMSO}_{6}, \delta\right.$ ppm): 112.9, $117.2(\mathrm{C} \equiv \mathrm{N}), 118.1,119.8,122.7,128.0,128.2,128.3,129.5,130.4,131.0,136.3$, 161.8 and 181.7 ( $\mathrm{Ar}-\mathrm{C}$ and $\mathrm{C}=\mathrm{O}$ ). Anal. calcd for $\mathrm{C}_{17} \mathrm{H}_{13} \mathrm{~N}_{5} \mathrm{O}$ (303.32): $\mathrm{C}, 67.32 ; \mathrm{H}, 4.32 ; \mathrm{N}$, 23.09. Found: $\mathrm{C}, 67.41 ; \mathrm{H}, 4.25 ; \mathrm{N}, 23.13$.

\section{2-Mercapto-5-oxo-1,7-diphenyl-1,5-dihydro-[1,2,4]triazolo[1,5-a]pyrimidine-6-carbonitrile} (12)

To ethanolic potassium hydroxide solution $(20 \mathrm{~mL})$ [prepared from $\mathrm{KOH}(0.01 \mathrm{~mol})$ in ethanol $(20 \mathrm{~mL})$ ], was added pyrimidine derivative $11 \mathbf{b}(0.01 \mathrm{~mol})$ and carbon disulfide $(0.01 \mathrm{~mol})$, the reaction mixture was refluxed for 6 hours, the formed precipitate was filtered off, dried and crystallized from ethanol to give white crystals from 12, yield $66 \%$, m.p. $>300^{\circ} \mathrm{C}$. IR $(\mathrm{KBr}$ $\left.\mathrm{cm}^{-1}\right): 3440(\mathrm{NH}), 2231(\mathrm{C} \equiv \mathrm{N}), 1680(\mathrm{C}=\mathrm{O}) .{ }^{1} \mathrm{H}$ NMR (DMSO-d $\left.{ }_{6}, \delta \mathrm{ppm}\right): 7.54-7.67(\mathrm{~m}, 10 \mathrm{H}$, Ar-H), 13.17 (s, $1 \mathrm{H}, \mathrm{SH})$. Anal. calcd for $\mathrm{C}_{18} \mathrm{H}_{11} \mathrm{~N}_{5} \mathrm{OS}$ (345.38): C, 62.60; H, 3.21; N, 20.28. Found: C, 62.68; H, 3.16; N, 20.35.

\section{5-Oxo-1,7-diphenyl-1,2,4,5-tetrahydro-[1,2,4]triazolo[1,5-a]pyrimidine-6-carbonitrile (13)}

To ethanolic sodium hydroxide solution $(20 \mathrm{~mL})$ [prepared from $\mathrm{NaOH}(0.01 \mathrm{~mol})$ in ethanol $(20 \mathrm{~mL})$ ], was added pyrimidine derivative $11 \mathbf{b}(0.01 \mathrm{~mol})$ and formaldehyde $(0.01 \mathrm{~mol})$. The reaction mixture was refluxed for 6 hours, the formed precipitate was filtered off, dried and crystallized from ethanol to give brown crystals from 13 yield $48 \%$, m.p. $>300{ }^{\circ} \mathrm{C} \cdot{ }^{1} \mathrm{H}$ NMR $\left(\mathrm{DMSO}_{6}, \delta \mathrm{ppm}\right): 3.32\left(\mathrm{~s}, 2 \mathrm{H}, \mathrm{CH}_{2}\right), 7.56-8.30(\mathrm{~m}, 10 \mathrm{H}, \mathrm{Ar}-\mathrm{H}), 11.85(\mathrm{~s}, 1 \mathrm{H}, \mathrm{NH})$. Anal. calcd for $\mathrm{C}_{10} \mathrm{H}_{7} \mathrm{~N}_{3} \mathrm{O}$ (185.18): C, 64.86; H, 3.81; N, 22.69. Found: C, 64.91; H, 3.77; N, 22.73.

Anticancer activity

Reagents. Fetal bovine serum (FBS) and L-glutamine were from Gibco Invitrogen Co. (Scotland, UK). RPMI-1640 medium was from Cambrex (New Jersey, USA). Doxorubicin, dimethyl sulfoxide (DMSO), penicillin, streptomycin and sulforhodamine B (SRB) were from Sigma Chemical Co. (Saint Louis, USA). 


\section{Cell cultures}

Three human tumor cell lines, MCF-7 (breast adenocarcinoma), NCI-H460 (non-small cell lung cancer), and SF-268 (CNS cancer) were used. MCF-7 was obtained from the European Collection of Cell Cultures (ECACC, Salisbury, UK) and NCI-H460 and SF-268 were kindly provided by the National Cancer Institute (NCI, Cairo, Egypt). They grow as monolayer and routinely maintained in RPMI-1640 medium supplemented with 5\% heat inactivated FBS, 2 $\mathrm{mM}$ glutamine and antibiotics (penicillin $100 \mathrm{U} / \mathrm{mL}$, streptomycin $100 \mu \mathrm{g} / \mathrm{mL}$ ) at $37{ }^{\circ} \mathrm{C}$ in a humidified atmosphere containing $5 \% \mathrm{CO}_{2}$. Exponentially growing cells were produced by plating $1.5 \times 10^{5}$ cells $/ \mathrm{mL}$ for MCF-7, SF-268 and $0.75 \times 10^{4}$ cells mL $\mathrm{mL}^{-1}$ for NCI-H460, followed by $24 \mathrm{~h}$ of incubation. The effect of the vehicle solvent (DMSO) on the growth of cell lines which it was evaluated in all experimental by exposing untreated control cells to the maximum concentration $(0.5 \%)$ of DMSO used in each assay.

\section{Tumor cell growth assay}

The effects of the newly synthesized compounds $\mathbf{2 , 5 , 1 0}$ and $\mathbf{1 1 b}$ on the in vitro growth of human tumor cell lines were evaluated according to the procedure adopted by the National Cancer Institute (NCI, USA) in the 'In vitro Anticancer Drug Discovery Screen' that uses the protein-binding dye sulforhodamine B to assess cell growth [27, 28]. Briefly, exponentially cells growing in 96-well plates were then exposed for $48 \mathrm{~h}$ to five serial concentrations of each compound starting from a maximum concentration of $150 \mu \mathrm{M}$. Following this exposure period adherent cells were fixed, washed and stained. The bound stain was solubilized and the absorbance was measured at $492 \mathrm{~nm}$ in a plate reader (Bio-Tek Instruments Inc., Power wave XS, Wincoski, USA). For each test compound and cell line, a dose response curve was obtained and the growth inhibition of $50 \%\left(\mathrm{GI}_{50}\right)$, corresponding to the concentration of the compounds that inhibited $50 \%$ of the net cell growth was calculated as described elsewhere. Doxorubicin was used as a positive control and tested in the same manner.

\section{RESULTS AND DISCUSSION}

In the present work, it is intended to investigate the synthetic possibilities of novel 2-amino-4oxo-4-phenyl-4H-1,3-thiazine-5-carbonitrile and its transformation to pyrimidine and condensed systems, The anticancer properties of the prepared compounds were screened in an attempt to determine new heterocyclic agents which could be useful as a hint in a drug discovery program.

One pot multicomponent reaction of benzaldehyde, thiourea and ethyl cyanoacetate in ethanolic potassium carbonate resulted in 1,3-thiazine cyclization affording aminocyanothiazinone derivative $\mathbf{1}$ as a kinetic controlled product (Scheme 1). The structure of aminothiazine 1 was supported by ${ }^{1} \mathrm{H}$ NMR which revealed signal at $\delta 13.07 \mathrm{ppm}$ for $\mathrm{NH}_{2}$ and multiplet at $\delta 7.32-7.68 \mathrm{ppm}$ for aromatic protons. The IR spectrum also showed the functional groups $\mathrm{C} \equiv \mathrm{N}$ and $\mathrm{C}=\mathrm{O}$ at $2232 \mathrm{~cm}^{-1}$ and $1688 \mathrm{~cm}^{-1}$, respectively. In addition to two bands at 3196 and $3153 \mathrm{~cm}^{-1}$ for $\mathrm{NH}_{2}$ group. The structure of aminothiazine $\mathbf{1}$ was also potentiated by ring transformation to pyrimidine derivatives by the effect of nitrogen nucleophile. The synthesis of the more stable product known as $N$-phenylaminopyrimidine derivative 2 was obtained as a result of the nucleophilic reaction of aniline with cyano-1,3thiazine derivative $\mathbf{1}$ in n-butanol (Scheme 1).

IR spectrum of 2 showed bands at $3427 \mathrm{~cm}^{-1}, 2206 \mathrm{~cm}^{-1}$ and $1675 \mathrm{~cm}^{-1}$ for $\mathrm{NH}_{2}, \mathrm{C} \equiv \mathrm{N}$ and $\mathrm{C}=\mathrm{O}$ groups, respectively. Its ${ }^{1} \mathrm{H}$ NMR spectrum displayed signals at $\delta 12.56 \mathrm{ppm}$ for $\mathrm{NH}_{2}$ and 7.49-7.69 ppm for aromatic protons. Compound 2 suffer acid induced ring opening upon treatment with $\mathrm{HCl}$ to produce the acid derivative 3 (Scheme 1). Its IR spectrum showed absorption bands at $3410,3172,2208$ and $1651 \mathrm{~cm}^{-1}$ corresponding to $\mathrm{OH}, \mathrm{NH} \mathrm{C} \equiv \mathrm{N}$ and $\mathrm{C}=\mathrm{O}$ 
groups, respectively. ${ }^{1} \mathrm{H}$ NMR spectrum showed signals at $\delta 11.5 \mathrm{ppm}$ for $\mathrm{OH}, 10.0 \mathrm{ppm}$ for $\mathrm{NH}$, and 7.41-7.73 ppm for aromatic protons. Also oxidative ring opening of cyanopyrimidine 2 was achieved by keeping compound 2 in $\mathrm{H}_{2} \mathrm{O}_{2}$ in the presence of $\mathrm{NaOH}$ in one pot flask to produce oxazine 4 (Scheme 1). Its IR spectrum showed bands at $3149 \mathrm{~cm}^{-1}$ for $\mathrm{NH}$ and 2206 , $1649 \mathrm{~cm}^{-1}$ for $\mathrm{C} \equiv \mathrm{N}$ and $\mathrm{CO}$ respectively. ${ }^{1} \mathrm{H}$ NMR spectrum showed signal at $\delta 10.10 \mathrm{ppm}$ for $\mathrm{NH}$ and 7.41-7.68 ppm for aromatic protons. Cyanothiazine derivative $\mathbf{1}$ undergo ring cleavage followed by heterocyclization producing $N$-hydroxypyrimidine derivative $\mathbf{5}$ in good yield $(77 \%)$ upon reaction with hydroxyl amine hydrochloride (Scheme 2). The structure was agreement with the spectral data (see the experimental section).
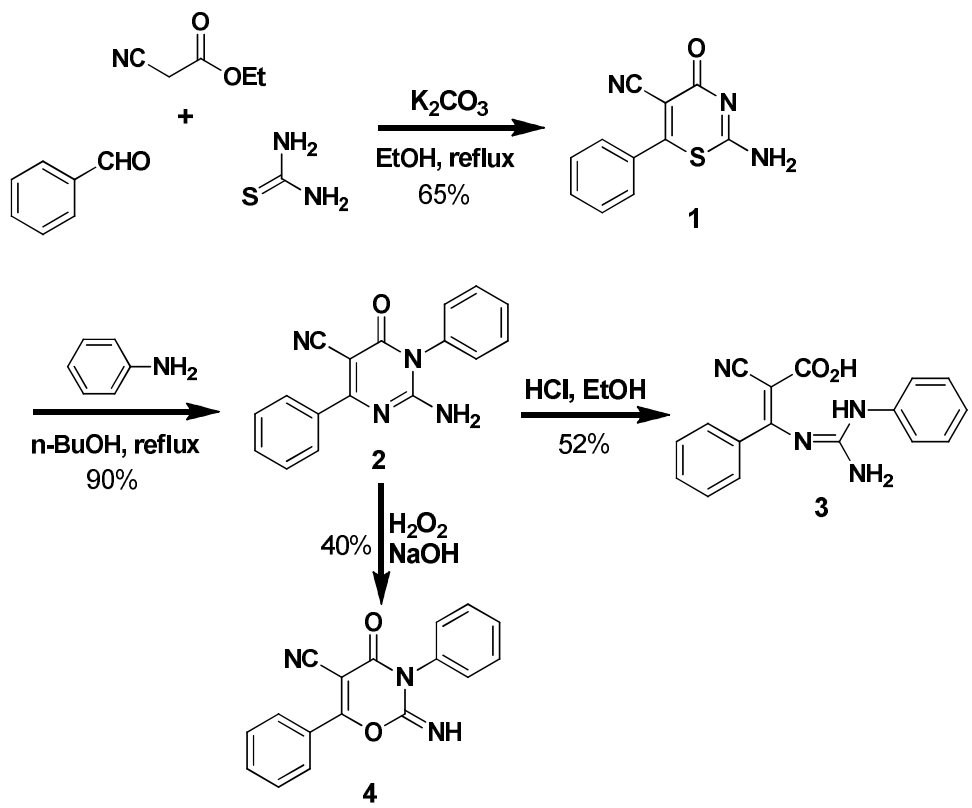

Scheme 1. Synthesis and reaction of 1,3-thiazine derivative 1.

Triazolopyrimidine of type $\mathbf{6}$ was prepared upon the reaction of thiazine derivative $\mathbf{1}$ with thiosemicarbazide in the presence of triethylamine (Scheme 2). IR spectra showed absorption bands at $3376 \mathrm{~cm}^{-1}$ for $\mathrm{NH}, 2213 \mathrm{~cm}^{-1}$ for $\mathrm{C} \equiv \mathrm{N}, 1622 \mathrm{~cm}^{-1}$ for $\mathrm{CO}$, and $1233 \mathrm{~cm}^{-1}$ for $\mathrm{SH} .{ }^{1} \mathrm{H}$ NMR spectrum showed signals at $\delta 12.25 \mathrm{ppm}$ for $\mathrm{SH}, 8.61 \mathrm{ppm}$ for $\mathrm{NH}$, and 7.51-7.71 ppm for aromatic protons. Compound 6 was transformed to the sulphonic acid derivative 7 by the oxidation with $\mathrm{I}_{2} / \mathrm{AcOH}$

Compound 1 undergo $\mathrm{N}$-alkylation upon the effect of ethyl iodide in presence of $\mathrm{NaOH}$ to give 8, which undergo ring opening followed by heterocyclizayion to give pyrazolone 9 upon treating with hydrazine hydrate (Scheme 2). The IR spectrum of 9 showed absorption bands at $3436 \mathrm{~cm}^{-1}$ for $\mathrm{NH}, 2221 \mathrm{~cm}^{-1}$ for $\mathrm{C} \equiv \mathrm{N}$, and $1646 \mathrm{~cm}^{-1}$ for $\mathrm{C}=\mathrm{O} .{ }^{1} \mathrm{H}$ NMR spectrum showed multiplet at $9.84 \mathrm{ppm}$ for $2 \mathrm{NH}$ protons and multiplet at $7.47-7.78 \mathrm{ppm}$ for aromatic protons.

Upon refluxing of amino-1,3-thiazine derivative $\mathbf{1}$ and ethyl bromoacetate in the presence of triethyl amine resulted $N$-alkylation producing bis- $N$ (ethoxy carbonyl methyl) thiazine derivative 10 (Scheme 2). IR spectrum showed absorption bands at $2223 \mathrm{~cm}^{-1}, 1735 \mathrm{~cm}^{-1}$, and $1661 \mathrm{~cm}^{-1}$ for $\mathrm{C} \equiv \mathrm{N}, \mathrm{C}=\mathrm{O}$ ester and $\mathrm{C}=\mathrm{O}$ amide respectively. ${ }^{1} \mathrm{H}$ NMR spectrum showed down field multiplet signal at $\delta 7.54-7.92 \mathrm{ppm}$ for aromatic protons, quartet signal at $4.08 \mathrm{ppm}$ for $\mathrm{CH}_{2} \mathrm{CH}_{3}$ and triplet at $1.11 \mathrm{ppm}$ for $\mathrm{CH}_{2} \mathrm{CH}_{3}$ protons, in addition to singlet at $2.5 \mathrm{ppm}$ 
corresponding to $\mathrm{NCH}_{2} \mathrm{CO}$ protons. The refluxing of 1,3-thiazine derivative $\mathbf{1}$ and hydrazine hydrate or phenyl hydrazine resulted in ring transformation affording diaminopyrimidine derivatives 11a,b, respectively (Scheme 2). The IR spectrum of 11a showed absorption bands at $3456,3221 \mathrm{~cm}^{-1}$ for $\mathrm{NH}_{2}$ groups, $2218 \mathrm{~cm}^{-1}$ for $\mathrm{C} \equiv \mathrm{N}$ group, and $1652 \mathrm{~cm}^{-1}$ for $\mathrm{C}=\mathrm{O}$ group. ${ }^{1} \mathrm{H}$ NMR spectrum showed signal at $\delta 7.15$ and $9.85 \mathrm{ppm}$ for $2 \mathrm{NH}_{2}$, in addition to aromatic protons at 7.45-7.78 ppm. The IR spectrum of 11 b showed bands at $3139 \mathrm{~cm}^{-1}$ for $\mathrm{NH}, \mathrm{NH}_{2}, 2206 \mathrm{~cm}^{-1}$ for $\mathrm{C} \equiv \mathrm{N}$ and $1634 \mathrm{~cm}^{-1}$ for $\mathrm{C}=\mathrm{O}$, its ${ }^{1} \mathrm{H}$ NMR showed signal at $\delta 11.76 \mathrm{ppm}, 10.38 \mathrm{ppm}$ for $\mathrm{NH}$ and $\mathrm{NH}_{2}$, and 6.74-8.08 ppm for aromatic protons. Compound 11b bearing of suitably located functionality for further cyclization, thus intremolecular cyclization of diaminopyrimidine derivative 11b with carbon disulphide afforded triazolopyrimidine derivative 12 (Scheme 2). IR spectrum of 12 showed bands at 3440, 2231, and $1680 \mathrm{~cm}^{-1}$ for $\mathrm{NH}, \mathrm{C} \equiv \mathrm{N}$, and $\mathrm{C}=\mathrm{O}$, respectively. Its ${ }^{1} \mathrm{H}$ NMR spectrum showed signal at $\delta 13.17 \mathrm{ppm}$ for $\mathrm{SH}$ and 7.54-7.70 ppm for aromatic protons. Using formaldehyde as cyclizing agent aiming to obtain triazole derivative $\mathbf{1 3}$ was obtained (Scheme 2). Its structure was agreement with the spectral data (see the experimental section).

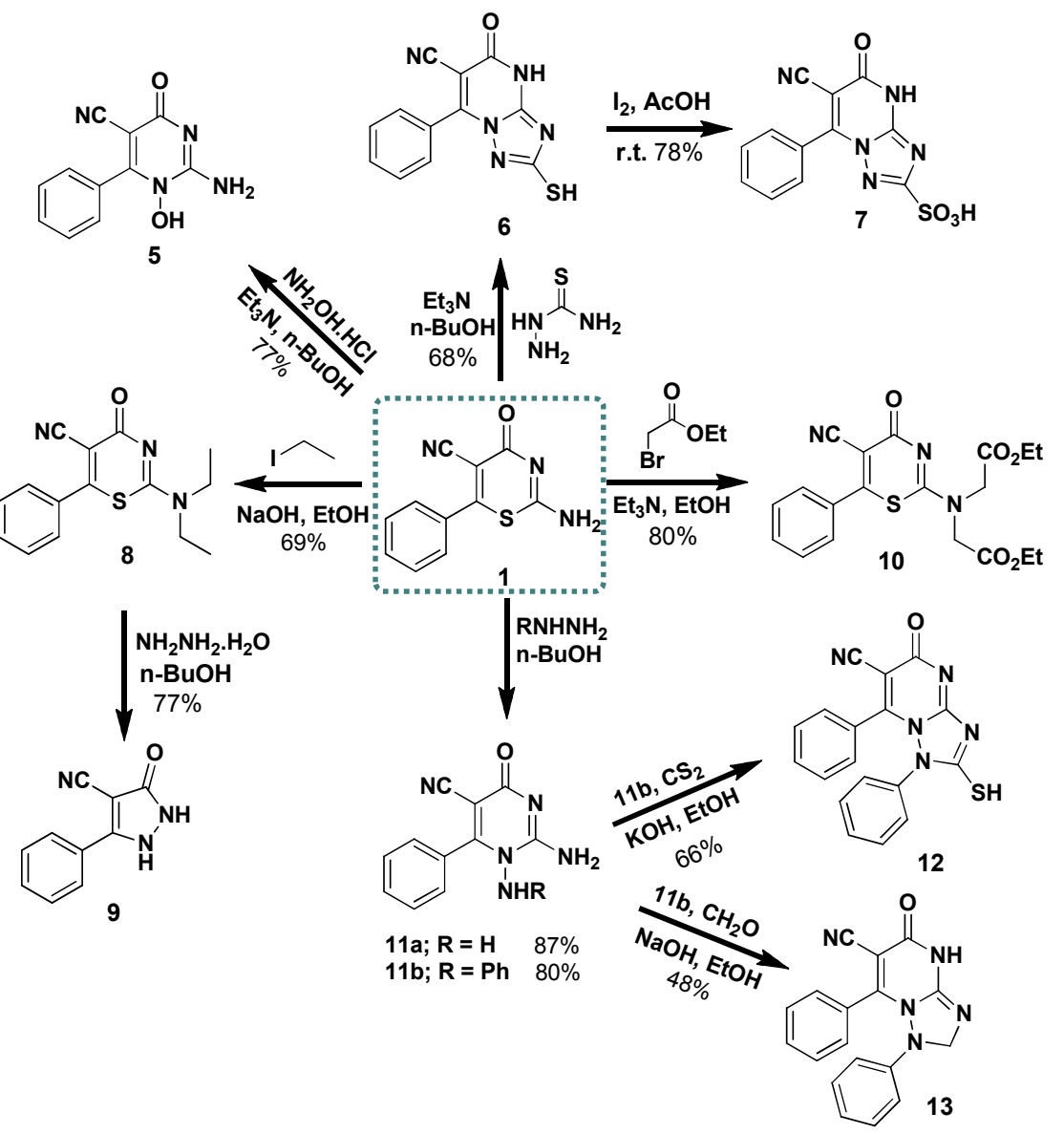

Scheme 2. Heterocyclization of 1,3-thiazine derivative 1.

Bull. Chem. Soc. Ethiop. 2018, 32(3) 
Anticancer activity

The results of anticancer activity are given in concentrations that were able to cause $50 \%$ of cell growth inhibition $\left(\mathrm{GI}_{50}\right)$ after a continuous exposure of 48 hours and show means $\pm \mathrm{SEM}$ of three independent experiments performed in duplicate (Table 1). Where diethyl-2,2 -((5-cyano4-oxo-6-phenyl-4H-1,3-thiazin-2-yl)azanediyl) diacetate (10) showed the highest inhibitory effects against all three tumor cell lines. Such activity is not higher than the corresponding reference doxorubicin, while 2-amino-6-oxo-1,4-diphenyl-1,6-dihydropyrimidine-5-carbonitrile (2), 2-amino-1-hydroxy-4-oxo-6-phenyl-1,4-dihydropyrimidine-5-carbonitrile (5) and 2-amino4-oxo-6-phenyl-1-(phenylamino)-1,4-dihydropyrimidine-5-carbonitrile (11b) showed lower inhibitory effect. It is obvious that by comparing the structures of the four compounds, we found that the presence of thiazine ring system substituted with bis- $N$-(ethoxy carbonyl methyl) is responsible for their reactivity over the compounds $\mathbf{2}, 5$ and $\mathbf{1 1 b}$, on the other hand, we can observe the presence of $\mathrm{NH}_{2}$ in compounds $\mathbf{2 , 5}$ and $\mathbf{1 1 b}$ decrease the anticancer activity.

Table 1. Effect of compounds $\mathbf{2 , 5 , 1 0}$ and $\mathbf{1 1 b}$ on the growth of three human tumor cell lines.

\begin{tabular}{|l|c|c|c|}
\hline \multirow{2}{*}{ Compound } & \multicolumn{3}{|c|}{$G_{50}, \mu \mathrm{mol} \mathrm{L}^{-1}$} \\
\cline { 2 - 4 } & NCI-H460 & MCF-7 & SF-268 \\
\hline $\mathbf{2}$ & $55.3 \pm 8.7$ & $60.0 \pm 10$ & $18.3 \pm 4.2$ \\
\hline $\mathbf{5}$ & $28.2 \pm 3.4$ & $18.3 \pm 4.2$ & $8.33 \pm 1.2$ \\
\hline $\mathbf{1 0}$ & $12.4 \pm 2.3$ & $8.33 \pm 1.2$ & $30.1 \pm 10$ \\
\hline $\mathbf{1 1 b}$ & $8.36 \pm 1.34$ & $30.1 \pm 10$ & $0.09 \pm 0.007$ \\
\hline Doxorubicin & $0.09 \pm 0.008$ & $0.04 \pm 0.008$ & \\
\hline
\end{tabular}

\section{REFERENCES}

1. Hushare, V.J.; Rajput, P.R.; Ghodile, N.G.; Malpani, M.O. Characterization of some novel heterocycles and their growth promoting effect on some flowering plants. J. Pharm. Technol. Res. 2013, 5, 420-425.

2. Tony, G.; Chandran, M.; Bhat, A.R.; Krishnakumar, K. Molecular docking studies: 1,3thiazine and 1,3-oxazine dervatives. J. Pharm. Res. 2014, 8, 136-138.

3. Szakonyi, Z.; Zupkó, I.; Sillanpää, R.; Fülöp, F. Stereoselective synthesis and cytoselective toxicity of monoterpene-fused 2-imino-1,3-thiazines. Molecules 2014, 19, 15918-15937.

4. Magd-El-Din, A.A.; Abd El-All, A.S.; Yosef H.A.; Abdalla M.M. Synthesis of potent antitumor oxo quinazoline, pyrazole and thiazine derivatives. Aust. J. Basic Appl. Sci. 2012, 6, 675- 685 .

5. Hassan, A.Y.; Said, M.M.; Sarg, M.T.; Al-Zahabi, H.S.; Hussein E.M. Utility of 2thiohydantoin derivatives in the synthesis of some condensed heterocyclic compounds with expected biological activity. Life Sci. J. 2013, 10, 1993-2011.

6. Dabholkar, V.V.; Parab, S.D. Synthesis of chalcones, 1,3-thiazines and 1,3-pyrimidines derivatives and their biological evaluation for antiinflammatory, analgesic and ulcerogenic activity. Heterocycl. Lett. Org. 2011, 1, 176-188.

7. Damanjit, C.S.; Simerpreet. Synthesis and biological evaluation of 1,3-thiazine - A review. Pharmacophore 2013, 4, 70-88.

8. Fu. L; Li, Y; Ye, D.; Yin, S. Synthesis and calming activity of 6H-2-amino-4-aryl-6- (4- $\beta$ D-allopyranosyloxyphenyl)-1,3-thiazine. Chem. Nat. Compd. 2010, 46, 169-172.

9. Jagodzinska, T.S.; Wesolowska, A.; Jagodzinski, E.; Rump, S. Synthesis and biological activity of certain novel derivatives of $1 H$-pyrrolo [1,2-c][1,3] thiazine. Acta Polomac Pharm. Drug Res. 2003, 60, 67-74. 
10. Hossaini, Z.; Nematpour, M.; Yavari, I. $\mathrm{Ph}_{3} \mathrm{P}-$ mediated one-pot synthesis of functionalized 3,4-dihydro- $2 H$-1,3-thiazines from N,N'-dialkylthioureas and activated acetlylenes in water. Monatsh Chem. 2010, 141, 229-232.

11. Vincent, G.; Baldwin, M.V.; Joseph, J.; Chandran, M.; Bhat, A.R.; Kumar, K.K. A review on biological activities of thiazine derivatives. Int. J. Pharm. Chem. Sci. 2014, 3, 341-348.

12. Jupudi, S.; Talari, S.; Karunakaram, D.R.G. Screening of in-vitro anti-inflammatory activity of some newly synthesized 1,3-thiazine derivatives. Int. J. Res. Pharm. Chem. 2013, 3, 2231-2781.

13. Haider, F.H.Z. Synthesis and antimicrobial screening of some 1,3-thiazines. J. Chem. Pharm.. Res. 2012, 4, 2263-2267.

14. Dandia, A.; Singh, R.; Saini, D. Ionic liquid-mediated three-component synthesis of fluorinated spiro-thiazine derivatives and their antimycobacterial and DNA cleavage activities. J. Chem. Sci. 2013, 125, 1045-1053.

15. Deepika, G; Gopinath, P.; Kranthi, G.; Nagamani, C.; Jayasree, Y.V.; Naidu, N.V.; Enaganti, S. Synthesis and antibacterial activity of some new thiazine derivatives. J. Pharm. Res. 2012, 5, 1105-1107.

16. Trofimova, T.P.; Zefirova, O.N.; Mandrugin, A.A.; Fedoseev, V.M.; Peregud, D. .; Onufriev, M.V.; Gulyaeva, N.V.; Proskuryakov S.Ya. Synthesis and study of NOSinhibiting activity of 2- $\mathrm{N}$-acylamono-5,6-dihydro-4H-1,3-thiazine. Moscow Uni. Chem Bull. 2008, 63, 274-277.

17. Rathod, A.K.; Kulkarni, G.B. Synthesis of 2-mercapto-dihydropyrimidines derivatives under conventional and microwave digestion technique and their anti-cancer and anti-tuberculosis activity. Int. J. Pharm. Technol. Res. 2011, 3, 728-731.

18. Venkatesan, K.; Satyanarayana, V.S.V.; Sivakumar, A. Synthesis of pyrimidine carboxamide derivatives catalyzed by uranylnitrate hexahydrate with antimicrobial and antioxidant studies. Bull. Chem. Soc. Ethiop. 2016, 30, 119-128.

19. Valluri, K.K.; Viswanath, I.V.K.; Naga Raju, P.V.V.S.; Rajasekher, B.; Dasu, B.R. Synthesis and in-vitro studies of some new quinoline 1,3,4-thiazdiazolo pyrimidne derivatives. Bull. Chem. Soc. Ethiop. 2017, 31, 337-344.

20. Joshi, V.D.; Kshirsagar, M.D.; Singhal, S. Synthesis and pharmacological study of some novel pyrimidines. Der Pharma Sinica 2012, 3, 343-348.

21. Taher, A.T.; Abou-Seri, S.M. Synthesis and bioactivity evaluation of new 6-aryl-5-cyano thiouracils as potential antimicrobial and anticancer Agents. Molecules 2012, 17, 9868-9886.

22. Bukhari, M.H. Synthesis, characterization and biological studies of pyrimidine related compounds, Ph.D. Thesis, Institute of Chemistry. University of the Punjab, Lahore, 2011.

23. Mahmoud, R.M.; El-Ziaty, A.K.; Ismail, M.F; Shiba, S.A. Synthesis of novel pyrimidine and fused pyrimidine derivatives. Eur. J. Chem. 2011, 2, 347-355.

24. El-Sayed, H.A.; Mostafa, A.H.; Haikal, A.Z.; Abdou, I.M.; El-Ashry, E.S.H. Synthesis and evaluation of antimicrobial activity of some pyrimidine glycosides. Nucleos. Nucleot. Nucl. Acids 2008, 27, 1061-1071.

25. El-Sayed, H.A.; Mostafa, A.H.; Haikal, A.Z.; Abu-El-Halwa, R.; El-Ashry, E.S.H. Synthesis, antitumor and antimicrobial activities of 4-(4-chlorophenyl)-3-cyano-2-( $\beta$ - $O$ glycosyloxy)-6-(thien-2-yl)-nicotinonitrile. Eur. J. Med. Chem. 2011, 46, 2948-2954.

26. Mostafa, A.H.; El-Sayed, H.A.; Haikal, A.Z.; Abd El-Hady, R.A. Synthesis and antimicrobial activity of some 2-pyridone nucleosides containing a sulfonamide moiety. Nucleos. Nucleot. Nucl. Acids 2013, 32, 221-238.

27. Campaigne, E. in Comprehensive Heterocyclic Chemistry, Vol. 4, Katritzky, A.R.; Rees, C.W. (Eds.), Pergamon Press: New York; 1984; p 863.

28. Monks, A.; Scudiero, D.; Skehan, P.; Shoemaker, R.; Paul, K.; Vistica, D.; Hose, C.; Langley, J.; Cronise, P.; Vaigro-Wolff, A.; Gray-Goodr, M.; Campbell, H.; Mayo, J.; Boyd, 
J.M. Feasibility of a high-flux anticancer drug screen using a diverse panel of cultured human tumor cell lines, J. Natl. Cancer Inst. 1991, 83, 757-766. 